\title{
Animal and plant response on renovated pastures in western Canada
}

\author{
DUANE H. MCCARTNEY, JOHN WADDINGTON, AND LEONARD P. LEFKOVITCH
}

Authors are pasture research leader, Agriculture and Agri -Food Canada, Melfort, SK SOE 1A0, Current Address: Lacombe Research Centre, 6000 $C \&$ E Trail, Lacombe, AB T4L 1W1; research scientist (retired), Agriculture and Agri-Food Canada Research Station, P.O. Box 1030, Swift Current, SK, S9H 3X2; and statistician (retired), Agriculture and Agri-Food Canada Research Branch, Headquarters, (Western Region), Ottawa, ON, K1A 0C6, Canada.

\begin{abstract}
Extending the present 4 month grazing season in the Aspen parklands of western Canada is of major economic interest to cow-calf producers. A long-term experiment was conducted on 375 ha to compare the present practice of continuous grazing with no fertilizer to a rotational grazing system of 4 paddocks fertilized in alternate years with $90 \mathrm{~kg} \mathrm{~N}, 45 \mathrm{~kg} \mathrm{P}_{2} \mathrm{O}_{5}$, $10 \mathrm{~kg} \mathrm{~S} \mathrm{ha}^{-1}$ and a 6 paddocks rotational grazing system including fertilizing and species replacement by cultivation and reseeding. Compared to the continuously-grazed control, the grazing period was extended by 14-days on the 4-paddock rotation system, and by a further 15-days on the 6-paddock rotation system, divided about equally between spring and fall. Forage yield, cow weight gains and calf growth were significantly improved, and year-to-year variation in forage yield and animal weight gain was reduced. In the 6-paddock rotation system, breaking 1 paddock at a time in summer after grazing, and reseeding the following spring caused no noticeable reduction in grazing capacity. Replacing the bromegrass (Bromus inermis Leyss.) dominated vegetation in 1 of the 6 paddocks with an early-growing grass contributed to the grazing season extension. Crested wheatgrass (Agropyron cristatum (L.) Gaertn.) performed well in this role; Russian wildrye (Psathyrostachys juncea (Fisch.) Nevski) died out within 6 years of seeding.
\end{abstract}

Key Words: Bromus inermis, Medicago sativa, Agropyron cristatum, Psathyrostachys juncea, Poa pratensis, pasture management

The Aspen Parkland of Western Canada stretches from southern Manitoba through central Saskatchewan to northern Alberta, and in its native state consists of poplar (Populus spp.) groves intermixed with rough fescue

The research was funded in part by grants from the Saskatchewan Horned Cattle Trust Fund, the Saskatchewan New Pastures and Grazing Technologies Committee, and Lands and Livestock Branch, Saskatchewan Agriculture and Food. The authors thank all the livestock and forage crew, Melfort Research Station, for their invaluable help in conducting the study.

Manuscript accepted 23 May 98

\section{Resumen}

Extensión del período de pastoreo cuatro meses practicado en la zona del parque de lamo tremblón (chopo) del oeste del Canadá, es de mucho interés para los criadores de vacas y terneros de la región. Un experimento de larga duración fue establecido y conducido en $\mathbf{3 7 5}$ ha para comparar los efectos de pastoreo rotativo en un sistema de cuatro parcelas fertilizadas en años alternados con $90 \mathrm{~kg} \mathrm{~N}, 45 \mathrm{~kg} \mathrm{P}_{2} \mathrm{O}_{5}$ y $10 \mathrm{~kg} \mathrm{~S}$ $\mathrm{ha}^{-1}$, con la practica presente de pastoreo continuo y con una combinación de pastoreo rotativo, fertilización y reemplazo de especies por medio de labranza y resiembra en un sistema de 6 parcelas. Comparado con el testigo de pastoreo continuo, el período de pastoreo fue extendido por 14 días en el sistema de 4 parcelas y por otros 15 días adicionales en el sistema de 6 parcelas; la extensión del período de pastoreo fue dividido igualmente entre primavera y otoño. Rendimiento de forraje ,ganancia de peso de las vacas y crecimiento de los terneros fueron mejorados significativamente y la variación anual fue reducida. En la rotación de 6 parcelas, labranza de una parcela al año después de concluido el pastoreo seguida de resienbra en la próxima primavera no causó una disminución perceptible del la capacidad de pastoreo del sistema. Reemplazando bromo liso (Bromus inermis Leyss.) en una de las parcelas por una especie con crecimiento temprano en la primavera contribuyó substancialmente a extender el período de pastoreo. Agropiro (Agropyrum cristatum (L .)Gaertn.) cumplió muy bien esta función; Psathyrostachys juncea (Fisch.) Nevski desapareció de la pastura dentro de 6 años de sembrado.

[Festucahallii (Vasey) Piper grasslands (Beacom 1991a, McCartney 1993). Abandoned farmlands and cleared poplar groves have been seeded with mixtures of bromegrass (Bromus inermis Leyss .), creeping red fescue (Festuca rubra L.), alfalfa (Medicago sativa L.), alsike clover (Trifolium hybridum L.) and sometimes small amounts of other species. The areas have been fenced into fields of varying sizes and grazed continuously from late May to early October, depending on rainfall. The term 'roughland bush pasture' well-describes these areas of uneven topography, stony soils, lakes, swamps, and poplar groves. 
Most of the research demonstrating the benefits of legumes, fertilizer, rotational grazing, etc. has taken place using steers and heifers on high quality, more uniform and flat land than that used for much of the grazing in the region (Cooke et al. 1968, Robertson et al. 1979). Since many of the commercial operations in the Aspen parkland are on low-quality land and concentrate on calf production, acceptance of the findings has been limited.

Fertility on these grazing lands is inherently low and the sward declines to low producing bromegrass-bluegrass (Poa pratensis L.) mixtures (McCartney 1994, McCartney and Bittman 1994, Nuttall et al. 1991). Increases in production were obtained by breaking up the old sward and reseeding with the same species as originally seeded. The falling response to repeats of this process, and the increased cost provided an opportunity to test the applicability of other rejuvenation methods on poor quality land (Cooke 1964).

A long-term large-scale rotational grazing study was established using cow-calf pairs on a working Aspen Parkland pasture to evaluate the application of fertilizer and rotational grazing for increasing forage production and animal performance on these depleted soils and to evaluate if the replacement of some of the resident vegetation with earlier-growing species would further increase pasture performance over the long term.

In keeping with current producer trends, cow-calf units were used for grazing along with January and April born calves. Since this was a working pasture it was essential to not reduce grazing capacity while rejuvenating the pastures.

\section{Materials and Methods}

\section{Experimental site}

In 1974, approximately 375 ha of Aspen Parkland pasture on a stony Orthic Gray Luvisol (Typic Cryoboralf, USDA-SCS 1975) was selected at Pathlow Community Pasture in northeastern Saskatchewan $\left(52^{\circ} 41^{\prime} \mathrm{N}, 104^{\circ} 58^{\prime} \mathrm{W}\right)$. This was typical of the many government operated pastures in the Aspen Parkland. The topography consists of small hills and depressions intermixed with flat and gently sloping areas, typical of glacial stagnation areas. The pasture was developed from abandoned farmsteads and aspen bushland in the mid 1960's by clearing most of the bush, and cultivating and seeding to a mixture of bromegrass, alfalfa, red fescue, and alsike clover. The area had been grazed continuously each growing season since, and by 1974 its carrying capacity had declined significantly. Soil fertility was extremely low (Nuttall et al. 1991).

\section{Experimental design}

In 1975 the area was cross-fenced to create 4-paddock and 6-paddock rotational grazing systems, each replicated 4 times, and a continuously-grazed area replicated twice. Each paddock in the rotational system was approximately 8 ha, and the continuouslygrazed areas were each approximately 16 ha. The cow-calf pairs used to graze the paddocks were randomly selected from groups that had calved in January-February (Early) or March-April (Late). They were allocated separately to the rotational grazing systems so that 2 replicates of each had early-born calves and 2 had late-born calves. The continuouslygrazed paddocks used cow-calf pairs from both early-and late-calving groups. All the paddocks in the 4- and 6- paddock rotational systems were fertilized with $90 \mathrm{~kg} \mathrm{~N}, 45 \mathrm{~kg} \mathrm{P}_{2} \mathrm{O}_{5}$ and $10 \mathrm{~kg} \mathrm{~S} \mathrm{ha}^{-1}$ in fall 1975 . Following this, to avoid large swings in productivity, half of the paddocks were fertilized at the same rates in late fall in 1977, 1979, 1981,1983, and 1985 , and the other half were fertilized in fall 1978, 1980, 1982, and early spring 1985 .

At some point in time, between 1975 and 1985, each paddock in the 6paddock system was cultivated in summer to destroy the resident vegetation and reseeded the following spring. This was the standard procedure used in the region. The exception was the fall of 1984 when glyphosate at $2.2 \mathrm{~kg} \mathrm{ha}^{-1}$ was used instead of cultivation. Vegetation was replaced in sequence by paddock so that the same number of animals could be maintained on the pasture for the duration of the experiment. Two paddocks per replicate were seeded in 1976 to Russian wildrye (Psathyrostachys juncea (Fisch.)Nevski 'Swift') at 5.6 $\mathrm{kg} \mathrm{ha}^{-1}$ and oats (Avena sativa $\mathrm{L}$.) at 19 $\mathrm{kg} \mathrm{ha}^{-1}$. In 1979 and in 1981, a paddock in each replicate was seeded to smooth bromegrass ('Carlton') at $9 \mathrm{~kg}$ $\mathrm{ha}^{-1}$, and alfalfa ('Rambler') at $2.2 \mathrm{~kg}$ $\mathrm{ha}^{-1}$. In 1983, one paddock per replicate was seeded to crested wheatgrass (Agropyron cristatum (L.) Gaertn. 'Parkway') at $9 \mathrm{~kg} \mathrm{ha}^{-1}$. The remaining paddocks were sod-seeded in 1985 to meadow bromegrass (Bromus riparius Rehm. 'Regar') at $9 \mathrm{~kg} \mathrm{ha}^{-1}$ and alfalfa at $2.2 \mathrm{~kg} \mathrm{ha}^{-1}$.

Each year, grazing commenced when the grass reached $10-15 \mathrm{~cm}$ in height, usually during the last week of May. Cows with calves born in January-February were stocked at 1.33 ha/cow calf pairs, and those with the smaller calves born in March-April at $1.11 \mathrm{ha} / \mathrm{cow}$ calf pair. This resulted in a stocking rate of $1.15 \mathrm{ha} / \mathrm{cow}$ calf pair for the 4-paddock system, 1.18 for the 6-paddock system and 1.84 for the continuously grazed control group. These densities were set to maximize the length of the grazing season for each grazing system. In 1976, the first year of grazing, insufficient cow-calf pairs were available for the control areas, so results are reported starting in 1977.

Due to heavy snow pack and the poor digestibility of over-wintered forages in the area, carry over of plant material is not practiced. In the 4-paddock rotational system, grazing commenced in a different paddock each year. In the 6-paddock rotational system, grazing started in 1 of the Russian wildrye paddocks, or in later years, in the crested wheatgrass paddocks. Cattle grazed in a paddock for 1 to 3 weeks and were moved to the next paddock when most of the forage had been consumed. Each paddock was grazed once or twice during the grazing season depending on forage production. Cows and calves were 
weighed separately before entering a paddock and on leaving it. At the start and end of the grazing season, animal weights were taken with water being restricted overnight. Calves were weaned about 2 weeks prior to completion of the grazing season, and removed from the pasture. Male calves were left intact until 1 month before weaning.

Forage dry matter yield was estimated each year using the double sampling cage technique (Cooke 1969). Six portable metal cages $(1.8 \times 2.7$ $\mathrm{m})$, pup tent style, were used in a paddock. Samples $(0.9 \times 2.7 \mathrm{~m})$ were harvested by clipping to about $5 \mathrm{~cm}$ stubble under the cage after cattle had been moved to the next paddock. A comparable area from outside the caged area was harvested for residual yield. In 1977 and 1987, samples from cage 1 and cage 4 were frozen, and later hand-separated into grasses, legumes, and weeds. All samples were dried to $100 \%$ dry matter and weighed. Using the same procedure, 2 areas located in an adjacent pasture outside the experimental area were also sampled to obtain additional forage yield and component information under the local producer's grazing management system.

\section{Statistical procedures}

The data analyzed consisted of forage dry matter yield, the proportions of grasses, legumes, and weeds, animal gains, and length of grazing season. Statistical analyses, all of which were performed using Genstat 5, release 2 (Lawes Agricultural Trust 1987), used generalized linear models. The structure within which each analysis consisted first of the block structure (years, paddocks etc.) and then the applied treatments. Forage yields, animal gains and number of grazing days were analyzed assuming a constant coefficient of variation (McCullagh and Nelder 1989), which is to be preferred over an analysis of variance when there is a positive association between the mean and the variance as is typical for these measures. The species composition was analysed assuming a "pseudo-binomial" distribution and a logit link, but with the dis- persion factor estimated from the residual mean deviance rather than assuming the unity value of the true binomial distribution. Tests of significance of responses were based on the ratio of the factors and interaction mean deviances to that of the residual mean deviance; these ratios were referred to the F-distribution. Probabilities less than 0.05 are deemed to be significant. Year and grazing system means separated by more than the sum of their standard errors were considered different.

\section{Results}

\section{Dry matter yield}

An analysis of deviance summarizes the effects of the various factors (Table $1)$. The significance of the main factors: year, grazing system, and fertilizer application is clear even without tests. The significant interaction between year and fertilizer is probably a result of the year-to-year variation in precipitation (Table 2). This did not significantly affect the relative forage production among the 3 grazing systems.

Table 1. Analysis of deviance for dry-matter yield in a pasture in northeastern Saskatchewan between 1977 and 1986.

\begin{tabular}{|c|c|c|}
\hline Source of variation & $\begin{array}{c}\text { Degrees } \\
\text { of Freedom }\end{array}$ & $\begin{array}{c}\text { Mean deviance } \\
\text { Ratio }^{1}\end{array}$ \\
\hline Year & 9 & $35.1 * *$ \\
\hline \multicolumn{3}{|l|}{ Grazing Systems $^{2}$} \\
\hline Rotation vs. Continuous & 1 & $182.51 * *$ \\
\hline Four vs. Six-Paddock & 1 & $17.08 * *$ \\
\hline Year $\times$ Grazing System & 18 & 1.2 \\
\hline Year X (Rotation vs. Continuous) & 9 & 1.58 \\
\hline Year $\times$ (Four vs. Six-Paddock) & 9 & 0.89 \\
\hline Fertilizer & 1 & $179.01 * *$ \\
\hline Year $\times$ Fertilizer $^{3}$ & 8 & $6.08 * *$ \\
\hline Residual & 397 & \\
\hline \multicolumn{3}{|c|}{ Analysis of deviance for average daily gain for cows } \\
\hline & Degrees & Mean deviance \\
\hline Source of variation & of Freedom & Ratio $^{1}$ \\
\hline Rep & 1 & 0.37 \\
\hline Year & 8 & $6.65^{* *}$ \\
\hline Calving time & 1 & 0 \\
\hline Year $\times$ calving time & 8 & 1.55 \\
\hline Rotation vs. Continuous & 1 & $5.49 * *$ \\
\hline Four vs. Six-Paddock & 1 & $5.23 * *$ \\
\hline Year X (Rotation vs. Continuous) & 8 & 1.42 \\
\hline Year $\times$ (Four vs. Six-Paddock $)$ & 8 & 2.78 \\
\hline Calving time (Four vs. Six-Paddock) & 1 & 2.67 \\
\hline Residual & 52 & \\
\hline
\end{tabular}

Annually over the period 1977 to 1986, there were no significant differences between production in the continuously-grazed experimental areas and the adjacent pasture (data not shown). Fields fertilized the previous fall averaged 160 percent more yield, and those fertilized 18 months previously yielded $58 \%$ more than the mean of $1,160 \mathrm{~kg} \mathrm{ha}^{-1}$ produced in the unfertilized continuously grazed paddocks (Table 3). The 4-paddock rotation system produced a significant $88 \%$ more forage than the continuously-grazed, non-fertilized areas, and the 6-paddock system with the reseeding produced a significant 18 percent more than the 4paddock system. The 6-paddock system produced little more than the 4paddock system until 1981 as the cumulative effect of reseeding did not occur until that time.

In general, grazing systems and treatments produced the least forage in 1980 and the most in 1984, although there were other years in which production was not significantly different from one of the high or low values. It 
Table 2. Precipitation at Melfort Research Station, $25 \mathrm{~km}$ northeast of Pathlow Community Pasture.

\begin{tabular}{|c|c|c|c|c|c|c|c|c|}
\hline \multirow[t]{2}{*}{ Year } & \multirow[b]{2}{*}{$\begin{array}{l}\text { Winter (Oct. prev. } \\
\text { yr. - } 30 \text { April) }\end{array}$} & \multicolumn{6}{|c|}{ Growing Season } & \multirow[b]{2}{*}{$\begin{array}{l}\text { Total } \\
\text { for Year }\end{array}$} \\
\hline & & May & June & July & August & Sept. & Total & \\
\hline 1976 & 93 & 47 & 90 & 123 & 42 & 6 & 306 & 401 \\
\hline 1977 & 96 & 120 & 28 & 63 & 77 & 73 & 361 & 457 \\
\hline 1978 & 162 & 22 & 99 & 47 & 62 & 50 & 280 & 442 \\
\hline 1979 & 205 & 40 & 68 & 26 & 42 & 14 & 190 & 395 \\
\hline 1980 & 170 & 2 & 82 & 41 & 79 & 24 & 228 & 398 \\
\hline 1981 & 115 & 7 & 40 & 105 & 12 & 77 & 241 & 356 \\
\hline 1982 & 187 & 73 & 34 & 88 & 63 & 19 & 277 & 464 \\
\hline 1983 & 143 & 23 & 67 & 130 & 50 & 68 & 338 & 481 \\
\hline 1984 & 137 & 101 & 104 & 51 & 18 & 68 & 342 & 479 \\
\hline 1985 & 215 & 73 & 66 & 21 & 48 & 33 & 241 & 456 \\
\hline 1986 & 97 & 49 & 40 & 109 & 33 & 77 & 308 & 405 \\
\hline 1987 & 64 & 42 & 20 & 78 & 86 & 13 & 239 & 303 \\
\hline Mean (12 yr) & 140 & 50 & 62 & 74 & 51 & 44 & 280 & 420 \\
\hline
\end{tabular}

was impossible to detect a positive relationship between the precipitation in any particular period and forage production. Very low precipitation in May $1980(2 \mathrm{~mm})$ clearly reduced forage production, but the low precipitation in May 1981 did not, even though precipitation the previous winter was lower than in 1979-80. Applying fertilizer and grazing rotationally resulted in 2.3 to 2.6 times more forage in the bestyielding year than in the poorest year, compared to a best: worst yearly production ratio of $3.4: 1$ in the continuously-grazed treatment without fertilizer.

\section{The effects of grazing systems on} forage constituents.

Significant changes occurred in the proportions of forage constituents between 1977 and 1987 with significant interactions between years and grazing systems, and years and species seeded (Table 4). In 1977, all paddocks except those seeded to Russian wildrye in 1976 contained the original species mix. In general, a decline in the proportion of legume dry matter and an increase in weeds is evident, with no change in grass content. In the 4-paddock system, the doubling of the weed component between 1977 and
1987 mirrored the decline in alfalfa. The proportion of grass in the forage did not change. In the 6-paddock system, reseeding to change the dominant species from the original bromegrass and creeping red fescue had mixed success. In paddocks seeded to Russian wildrye, this grass made up $70 \%$ of the total dry matter in 1977 . In the years following, all the species previously present, except alfalfa, reestablished with smooth bromegrass and Kentucky bluegrass being dominant. By 1987 Russian wildrye was confined to dry knolls. After establishment in 1983, crested wheatgrass dominated the vegetation, produced $97 \%$ of the forage in 1987 , and provided excellent early spring and late fall grazing. The contrast in weed content with the Russian wildrye paddocks probably reflects the more competitive nature of crested wheatgrass. Reseeding with brome-alfalfa prevented the reduction in alfalfa that occurred in the 4-paddock system, but did not prevent an increase in weeds. Kentucky bluegrass, present in low quantities in all paddocks at the beginning of the study, increased, and by 1987 was estimated to contribute up to $15 \%$ of the total yield.

The effects of management systems on grazing season length.

During the course of the study the earliest date when pastures were ready to graze varied from 16 May for the 6-

Table 3. Estimated dry matter production (standard error) by year and treatment in a pasture in northeastern Sakatchewan between 1977 and 1985.

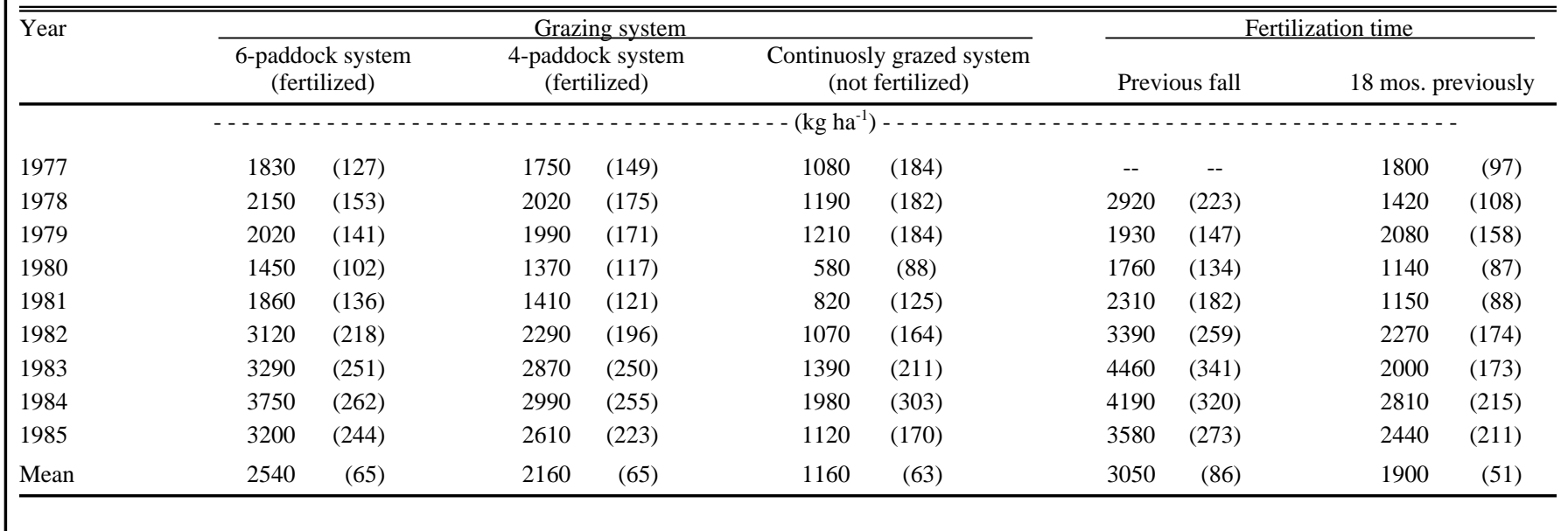


Table 4. Mean values (standard errors) of proportions of dry matter of species groups present on a pasture in northeastern Saskatchewan in 1977 and 1987 before and after reseeding.

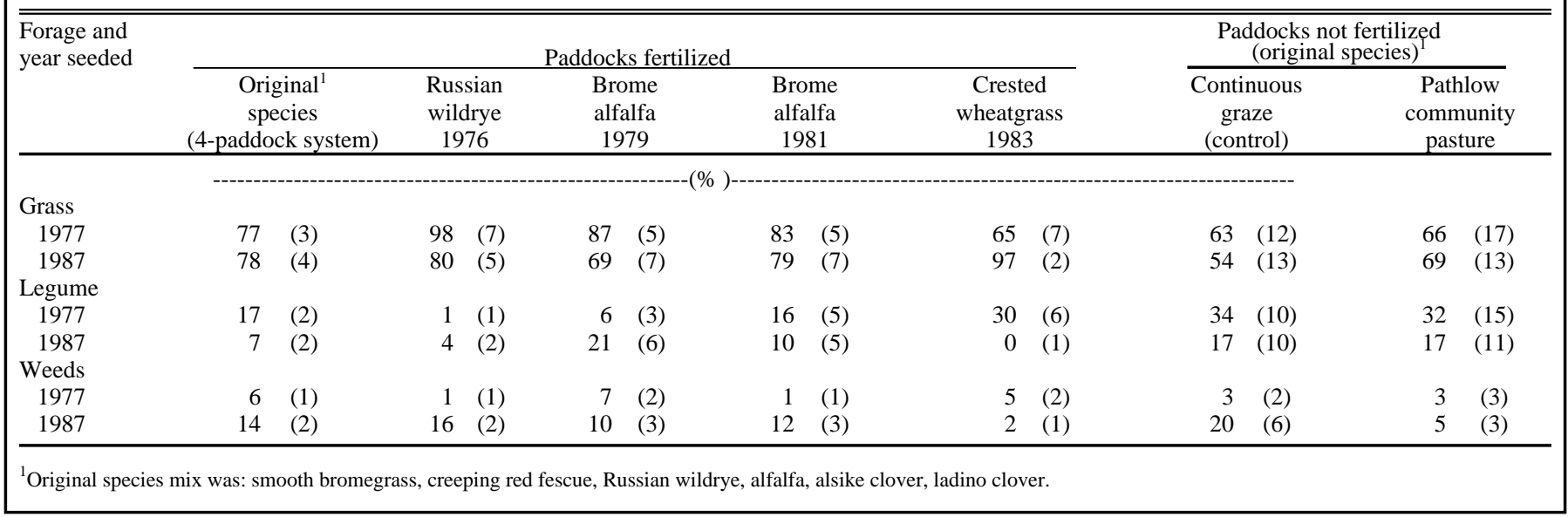

paddock system to the latest date of 17 June for the continuously grazed, nonfertilized system. On average cattle commenced grazing in the 6-paddock system 5 days earlier than in the 4 paddock system and 11 days earlier than in the continuously grazed control treatment. In the 6-paddock system this was due to the earlier growth of the Russian wildrye and in later years the crested wheatgrass, and in the 4-paddock system, to fertilizer application. The latest day for fall grazing was 1 November for the 6paddock system. The average length of grazing season for the 4-paddock system was 1 June to 8 October (129 days), the 6-paddock system was 26 May to 17 October (144 days) and for the continuously grazed system, 6 June to 29 September (115 days).

\section{Cow performance during the grazing season}

Over the experimental period, average daily gain (ADG) was significantly greater on the rotational grazing than on the continuous grazing treatments, and the 4 paddock system was superior to the 6 paddock system (Table 1). On a yearly basis there were no consistent differences between grazing systems (Table 5).

Overall, continuous grazing resulted in poorer gain $\mathrm{ha}^{-1}$ than rotational grazing (Table 6). On a yearly basis, weight gain ha-1 was consistently poorer on continuously grazed areas compared to the 4 paddock system but less consistent when compared to the 6 paddocks system. There were no clear differences in gain ha $^{-1}$ between early and late calving cows.

\section{Calf performance during the graz- ing season}

Average daily gain (ADG) for the calves on the 4 paddock system and the continuously grazed treatments were significantly greater than the gain on calves on the 6 paddock system when averaged over the years (Table 7). However there were no consistent differences between grazing treatments on a yearly basis. Cows and calves heavily grazed the continuously grazed control area and grazing material was very short and usually consisted of regrowth material which

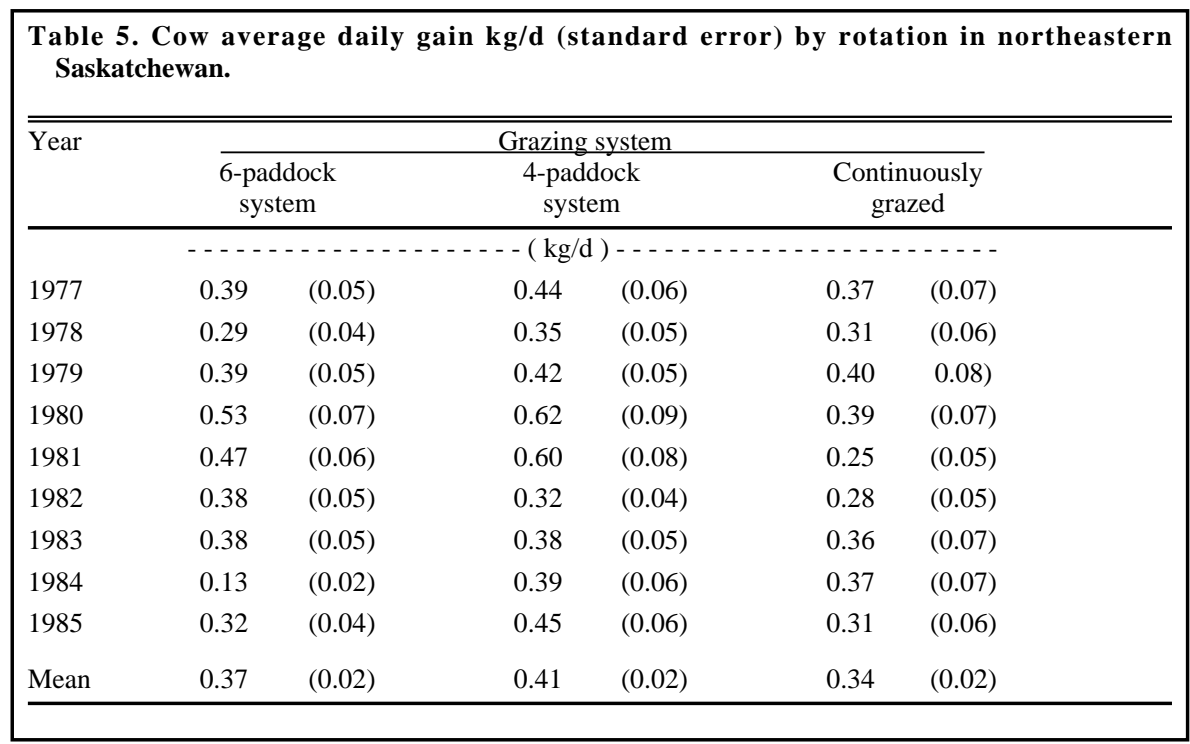

was of high nutritional quality. The ratio of best: poorest year for average daily gains was $1.3: 1$ in the rotations and 1.6:1 in the control. On average, early-born calves had better rates of gain than late-born calves. However, this was not the case each year as ADG was similar in some years.

Average calf gain $\mathrm{ha}^{-1}$ was greater in the 6 paddock system than in the 4 paddock system, but this was not consistent on a yearly basis (Table 8). However both the 4 paddock and 6 paddock system had greater gains than the continuously grazed non-fertilized treatments except in 1977. Overall, and in 8 of 9 years, late-born calves gained more ha-1.

It is recognized that animal-unitmonths ha ${ }^{-1}$ is partly dependent on the beginning and ending dates of the 
Table 6. Cow weight gain kg per hectare (standard error) by grazing systems and calving time in northeatern Saskatchewan.

\begin{tabular}{|c|c|c|c|c|c|c|c|c|c|c|}
\hline \multirow[t]{2}{*}{ Year } & \multicolumn{6}{|c|}{ Grazing system } & \multicolumn{4}{|c|}{ Calving time } \\
\hline & \multicolumn{2}{|c|}{ 6-paddock system } & \multicolumn{2}{|c|}{ 4-paddock system } & \multicolumn{2}{|c|}{ Continuosly grazed } & \multicolumn{2}{|c|}{ Early (Jan.) } & \multicolumn{2}{|c|}{ Late (Mar.) } \\
\hline 1977 & 52 & (5.4) & 50 & $(5.2)$ & 44 & (6.5) & 48 & (4.3) & 54 & (5.6) \\
\hline 1979 & 46 & $(4.8)$ & 51 & $(5.5)$ & 37 & $(5.5)$ & 48 & $(4.4)$ & 43 & $(4.5)$ \\
\hline 1980 & 45 & $(4.7)$ & 45 & $(4.7)$ & 19 & $(2.8)$ & 39 & (3.7) & 47 & $(4.9)$ \\
\hline 1981 & 45 & $(4.7)$ & 45 & $(4.7)$ & 13 & (1.9) & 36 & (3.5) & 51 & $(5.3)$ \\
\hline 1983 & 44 & $(4.6)$ & 41 & $(4.3)$ & 17 & (2.4) & 39 & (3.4) & 39 & $(4.7)$ \\
\hline 1984 & 23 & $(2.4)$ & 35 & (3.8) & 18 & (2.6) & 28 & (2.6) & 29 & $(3.0)$ \\
\hline 1985 & 38 & (3.9) & 52 & $(5.4)$ & 15 & $(2.3)$ & 37 & (3.6) & 50 & $(5.2)$ \\
\hline Mean & 43 & (1.5) & 45 & (1.6) & 23 & (1.3) & 40 & $(1.2)$ & 44 & (1.6) \\
\hline
\end{tabular}

Table 7. Calf average daily gain kg/d (standard error) by grazing systems and calving time in northeastern Saskatchewan.

\begin{tabular}{|c|c|c|c|c|c|c|c|c|c|c|}
\hline \multirow[t]{2}{*}{ Year } & \multicolumn{6}{|c|}{ Grazing system } & \multicolumn{4}{|c|}{ Calving time } \\
\hline & \multicolumn{2}{|c|}{ 6-paddock system } & \multicolumn{2}{|c|}{ 4-paddock system } & \multicolumn{2}{|c|}{ Continuously grazed } & \multicolumn{2}{|c|}{ Early (Jan.) } & \multicolumn{2}{|c|}{ Late (Mar.) } \\
\hline 1977 & 0.89 & $(0.02)$ & 0.99 & $(0.02)$ & 0.83 & $(0.03)$ & 0.93 & $(0.02)$ & 0.91 & $(0.02)$ \\
\hline 1978 & 0.90 & $(0.02)$ & 0.96 & $(0.02)$ & 0.97 & $(0.03)$ & 0.95 & $(0.02)$ & 0.90 & $(0.02)$ \\
\hline 1979 & 0.91 & $(0.02)$ & 0.98 & $(0.02)$ & 0.97 & $(0.03)$ & 0.97 & $(0.02)$ & 0.92 & $(0.02)$ \\
\hline 1980 & 1.09 & $(0.02)$ & 1.18 & $(0.03)$ & 1.18 & $(0.04)$ & 1.14 & $(0.02)$ & 0.15 & $(0.02)$ \\
\hline 1981 & 1.15 & $(0.02)$ & 1.18 & $(0.03)$ & 1.11 & $(0.03)$ & 1.16 & $(0.02)$ & 1.15 & $(0.02)$ \\
\hline 1982 & 1.05 & $(0.02)$ & $1 . .07$ & $(0.02)$ & 1.14 & $(0.04)$ & 1.09 & $(0.02)$ & 1.04 & $(0.02)$ \\
\hline 1983 & 1.07 & $(0.02)$ & 1.07 & $(0.02)$ & 1.29 & $(0.04)$ & 1.12 & $(0.02)$ & 1.05 & $(0.03)$ \\
\hline 1984 & 1.00 & $(0.02)$ & 1.12 & $(0.02)$ & 1.20 & $(0.04)$ & 1.12 & $(0.02)$ & 1.00 & $(0.02)$ \\
\hline 1985 & 1.15 & $(0.03)$ & 1.19 & $(0.03)$ & 1.20 & $(0.04)$ & 1.22 & $(0.02)$ & 1.18 & $(0.02)$ \\
\hline Mean & 1.02 & $(0.01)$ & 1.08 & $(0.01)$ & 1.10 & $(0.01)$ & 1.08 & $(0.01)$ & 1.02 & $(0.01)$ \\
\hline
\end{tabular}

Table 8. Calf weight gain kg per hectare (standard error) by grazing systems and calving time in northeatern Saskatchewan.

\begin{tabular}{|c|c|c|c|c|c|c|c|c|c|}
\hline \multirow[t]{2}{*}{ Year } & \multicolumn{6}{|c|}{ Grazing system } & \multicolumn{3}{|c|}{ Calving time } \\
\hline & \multicolumn{2}{|c|}{ 6-paddock system } & \multicolumn{2}{|c|}{ 4-paddock system } & \multicolumn{2}{|c|}{ Continuosly grazed } & \multicolumn{2}{|c|}{ Early (Jan.) } & Late (Mar.) \\
\hline 1977 & 78 & $(2.7)$ & 72 & $(2.4)$ & 70 & $(2.4)$ & 72 & (21) & $77 \quad(26)$ \\
\hline 1979 & 86 & (2.9) & 91 & (3.1) & 60 & (2.9) & 82 & (2.5) & $89(3.0)$ \\
\hline 1980 & 72 & (2.4) & 68 & (2.3) & 53 & $(2.5)$ & 64 & (1.9) & $75 \quad(2.5)$ \\
\hline 1981 & 90 & (3.1) & 86 & (2.9) & 50 & (2.4) & 78 & (2.3) & $93 \quad(3.2)$ \\
\hline 1984 & 118 & $(4.1)$ & 93 & $(3.2)$ & 52 & $(2.5)$ & 96 & (3.0) & 104 \\
\hline 1985 & 110 & (3.8) & 105 & (3.7) & 54 & $(2.8)$ & 101 & (3.1) & 99 (3.4) \\
\hline Mean & 96 & $(1.1)$ & 89 & $(1.0)$ & 58 & $(0.9)$ & 84 & $(0.8)$ & $93(1.1)$ \\
\hline
\end{tabular}




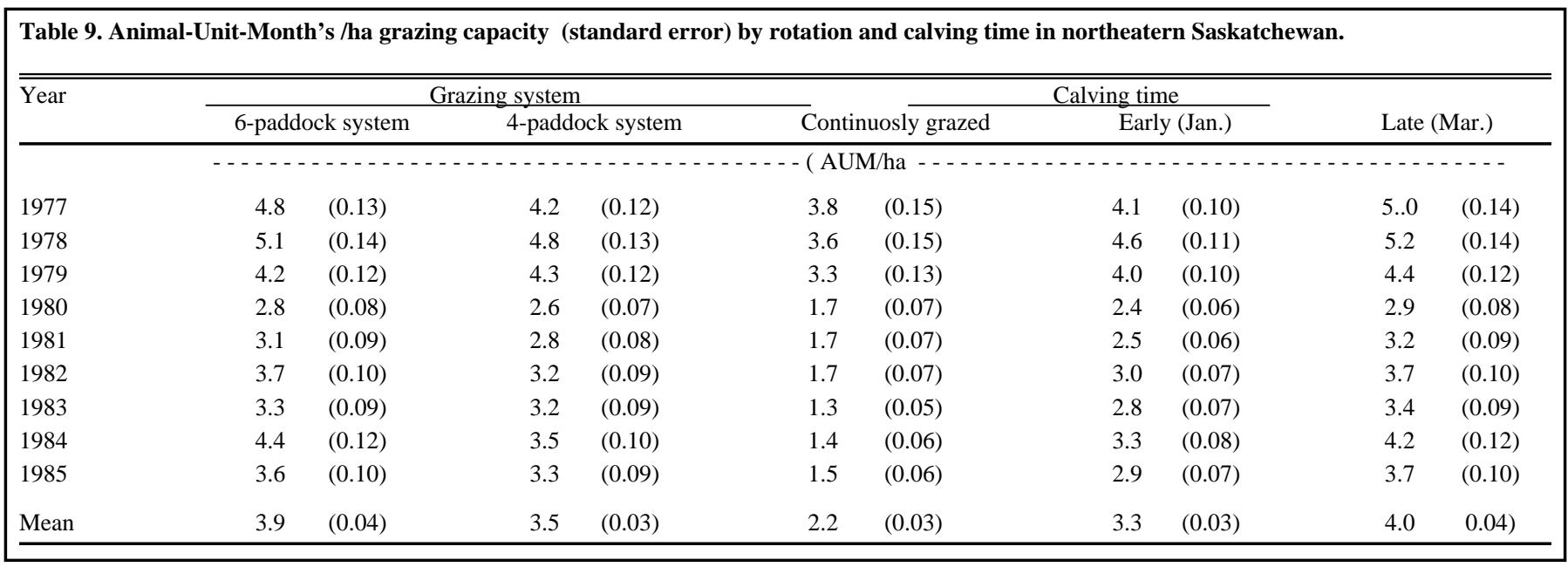

grazing season and should be interpreted with some caution. They were established at the beginning of each grazing season on the expected forage production for the year. Producers in Canada traditionally use their historical AUM information and establish their stocking rates accordingly at the start of each grazing season.

By the animal-unit-months ha ${ }^{-1}$ measure for cow calf pairs, the 6-paddock system was significantly better than the 4-paddock system, 3.9 vs. 3.5 (Table 9). Both rotations were superior to the control at 2.2 animal-unit months ha ${ }^{-1}$. The ratio of best: poorest year was 1: 1.8 in the rotations compared to 1: 2.9 for the control treatment. Each year there were significantly more animal-unit-months of grazing for late calves than early calves.

\section{Discussion}

The maximum possible length of grazing season in northeastern Saskatchewan is about 170 days. There is never sufficient growth to sustain grazing before mid-May, and by the end of October forage quality has deteriorated to below maintenance requirement of the beef cow. In addition, a late spring snowstorm may prevent early grazing, as occurred in 1977, and snow cover may prevent grazing the standing forage in October, as occurred in 4 of the 9 years of study. The 6-paddock system achieved $85 \%$ of this maximum, com- pared to $76 \%$ by the 4-paddock system and $68 \%$ by the continuously-grazed control treatment. In both systems, slightly less than half the additional time was gained in spring when forage quality is very high, and the rest gained in fall when forage quality is usually low. It seems likely that the 6paddock system is at the maximum practical limit of grazing period for standing forage in the aspen parkland. This applies only to grazing cows after the calves have been removed. Stocker steers as used by Cooke et al.(1973) and Robertson et al. (1979) are not allowed to graze as long in fall because they lose weight on the poorquality grass.

The extension of the grazing season from 115 days on the continuouslygrazed control to 129 days on the 4paddock system and 144 days on the 6-paddock system is of great significance to cow-calf producers in the northern area of western Canada. Stored feed accounts for the greatest proportion of winter costs, so extending the grazing season is beneficial economically (Beacom 1991b). As well, all cows entered the winter in good body condition regardless of grazing system.

Pastures dominated by smooth bromegrass can be regarded as a more-or-less stable 'climax' vegetation of well-adapted introduced grasses (Looman 1976). The native broadleaf plants which form the 'weed' component occupy the same niches as they do in native grassland communities. Fertilizing bromegrass in fall, which results in faster growth of more vigorous, better quality tillers the following spring (Waddington 1968), probably accounts for the earlier readiness for grazing of the 4-paddock system compared to the unfertilized control paddocks. The additional 5-day gain in readiness for grazing of the 6-paddock system, due to the earlier growth of Russian wildrye and crested wheatgrass, was slightly better than that observed by Cooke et al. (1973).

The use of the double-sampling cage technique allowed us to estimate forage disappearance. Because cows grazed until almost all the forage had disappeared, utilization ranged from 80 to $90 \%$. Losses from trampling, senescence, etc. which are included in this estimate, were observed to be low. Based on forage estimates and cow gains, daily forage disappearance averaged $3.7 \%$ of their body weight. When the weight of the calf over the grazing period was included, forage disappearance averaged $2.8 \%$ of the total cow-calf weight. It appears that the present value used to estimate forage requirements of $2.6 \%$ of body weight for a $454 \mathrm{~kg}$ cow or $11.8 \mathrm{~kg}$ forage dry matter per day (Jacoby 1989, NRC 1984), is too low for eastcentral Saskatchewan conditions.

Although the early-born calves had greater daily rates of gain than the late-born calves, the slightly higher stocking rate on the paddocks with late calves resulted in significantly greater gain per hectare than on the others. Producers in the region who 
are moving their calving season to February-March from April-May to get heavier calves for the fall sales, may find gains on an area basis to be lower than before.

Most of the performance measures used, but forage production in particular, showed less year-to-year variation in fertilized and rotationally grazed areas than in the control. This is a very useful finding, because one of the major problems producers face is balancing cattle numbers with the yearto-year variation in forage production caused by weather vagaries (Bittman et al. 1997). In the 6-paddock system, renovating one paddock at a time in succession had little negative impact on productivity because the paddock was grazed before breaking in early summer, and was grazed in late summer the following year after seedlings were well-established. '

Much of the variation in cow performance on the control areas was caused by the large difference between results from 1977-79 and from 1980-85. Apparently, these areas were unable to recover following the stress caused by drought in 1980. The low cow weight gain in the 6-paddock system in 1984 was caused by a severe snow storm the day before the cattle were due to be removed. Consequently, they spent 2 days without food and water which resulted in a large shrink.

In summary the use of fertilizer and rotational grazing significantly increased forage yield and animal gain, and decreased year to year variability. Crested wheatgrass and Russian wildrye fertilized and rotationally grazed extended the grazing season, and could be established without any reduction in grazing capacity. Russian wildrye established well but did not persist.

\section{Literature Cited}

Beacom, S.E. 1991a. Pasturing forage crops in the Aspen Parklands of Western Canada. Agr. Canada, Publ. 1872/E.

Beacom, S.E. 1991b. Feeding forage crops in the Aspen Parkland of Western Canada. Agr. Canada, Publ. 1874/E.

Bittman, S., D.H. McCartney, J. Waddington, P.R. Horton, and F. Nuttall, 1997. Long term effects of fertilizer on yield and species composition of contrasting pasture swards in the Aspen Parkland of the Northern Great Plains. Can. J. Plant Sci. 77: 607-614.

Cooke, D.A. 1964. Progress report of pasture research in the Garrich Community Pasture 1962-1963. Proceedings of Development of Pasture from bushlands in Western Canada, Regina, SK. April 1964. Canada Dept. Of Agr., Ottawa. pp. 31-35.

Cooke, D.A. 1969. Experimental methods for evaluating herbage. Can. Dept. Agr. Publ. 1315. The Queen's Printer, Ottawa, Ont. pp. 80-90.

Cooke, D.A., S.E. Beacom, and W.K. Dawley, 1968. Response of six-year-old grass-alfalfa pastures to nitrogen fertilizer in northeastern Saskatchewan. Can. J. Plant Sci. 48: pp.167-173.

Cooke, D.A., S.E. Beacom, and J.A. Robertson, 1973. Comparison of continuously grazed bromegrass-alfalfa with rotationally grazed crested wheatgrass-alfalfa, bromegrass-alfalfa and Russian wild ryegrass. Can. J. Anim. Sci. 53:423-429.

Jacoby, P.W. 1989. A glossary of terms used in range management. Soc. for Range Management, Denver, Colo. pp1

Lawes Agricultural Trust. 1987. Genstat 5 Reference Manual. Clarendon Press, Oxford.

Looman, J. 1976. Productivity of permanent bromegrass pastures in the Parklands of the Prairie Provinces. Can. J. Plant Sci. 56: 829-835.

McCartney, D.H. 1993. History of grazing research in the Aspen Parkland. Can. J. Anim. Sci. 73: 749-763.

McCartney, D.H. and S. Bittman, 1994. Persistence of cool season grasses under grazing using the mob-grazing technique. Can. J. Plant Sci. 74:723-728.
McCullagh, P. and J.A. Nelder, 1989. Generalized linear models (2nd edition). Chapman and Hall, London.

NRC. 1984. Nutrient requirements of beef cattle. National Academy Press, Washington, D.C. 6th ed.

Nuttall, W.F., D.H. McCartney, S. Bittman, P.R. Horton, J. Waddington, 1991. The effects of $\mathrm{N}, \mathrm{P}$, and $\mathrm{S}$ fertilizer, temperature and precipitation on the yield of bromegrass and alfalfa pasture established on a Luvisolic soil. Can. J. Plant Sci. 71: 1047-1055.

Robertson, J.A., D.A. Cooke, and S.E. Beacom, 1979. A comparison of four systems of managing yearling beef steers on rotationally grazed bromegrass-alfalfa pastures. Can. J. Anim. Sci. 59:519-529.

USDA-SCS. 1975. Soil taxonomy: a basic system of soil classification for making and interpreting soil surveys. Agr. Handb. 436. U.S. Gov. Print. Off. Washington, D.C.

Waddington, J. 1968. The influence of management practices on the growth cycle of Bromus inermis Leyss. in southern Manitoba. Ph.D. Thesis, Univ. of Manitoba, 167 pp. 